\title{
British Museum'da Sergilenen Klasik Osmanlı Dönemi İznik Seramikleri
}

\author{
Azize Melek ÖNDER*
}

Özet

Klasik Osmanlı döneminde üretilen seramikler genel bir çerçevede değerlendirildiğinde birçok farklı kap tipinin üretilmeye başladığını görebiliriz. Bu dönemde üretilen kaplarda görülen artışın sebebi Osmanlı devletinin bir imparatorluk olmasından ileri gelmektedir. Bu sayede dönemin ihtiyaçlarına cevap verebilen kaplar üretilmeye başlamış ve belirli bir zamandan sonra koleksiyonlarda yerlerini alan eserler haline dönüşmüştür.

Bu çalışma, British Museum'da online olarak sergilenen Klasik Osmanlı Dönemi seramiklerine ait 25 farklı kapalı kap biçimi üzerine yapılmış bir araştırmadır. Bu kaplar üretim biçimlerine göre farklı isimlerde altında gruplandırılmıştır. Her grup kendi içerisinde üretim özelliklerine göre alt gruplara ayrılmış ve genel özellikleri verilmiştir.

Anahtar Sözcükler: British Museum, Klasik Osmanlı, İznik, Seramik

\section{Classıcal Ottoman Perıod Performance Ceramıcs Showed In Britısh Museum}

\section{Abstract}

The evaluation of the ceramics produced in Classical Ottoman period indicates that many different types of vessels were being produced. The reason for the increase in the cups produced in this period was that the Ottoman state was an empire. This way, pots that could respond to the needs of the period began to be produced and in time, they were transformed into collection items.

This study is a research on 25 different closed vessel forms used in Classical Ottoman ceramics, which are exhibited online at British Museum. These containers are grouped under different names according to their production patterns. Each group is classified into suc-groups according to their production characteristics and general characteristics of these subgroups are discussed.

Keywords: British Museum, Classical Ottoman, İznik, Ceramic 


\section{Giriş}

Osmanlı döneminde seramik üretiminin en önemli merkezi İznik olarak kabul edilmektedir. Osmanlı saraylarının iç dekorasyonundan küçük ev gereçlerine kadar birçok alanda üretim yapan İznik 16. yüzyılda en verimli dönemini yaşamıştır. Bu dönemde üretilen seramiklerin bir kısmının yurt dışına ihraç edilmiş olduğu bugün farklı ülkelerin müzelerindeki koleksiyonlardan anlaşılmaktadır. Bu müzelerden bir tanesi de İngiltere'de bulunan British Museum'dur.

British Museum 1753 yılında dünyanın ilk ulusal müzesi olarak kurulmuştur. British Museum'un kökenleri hekim, doğa bilimci ve koleksiyoncu Sir Hans Sloane'ın (1660-1753) yaşamı boyunca topladığı 71.000'den fazla nesneden oluşmaktadır. İlk toplanan eserler büyük ölçüde kitap, el yazması, bazı antikalar (madeni para ve madalyalar, baskılar ve çizimler dâhil) ve yöresel malzemeleri içermektedir. Müze günümüzde dünya kültürlerinin tarihini kapsayan 8 milyondan fazla nesneyi bünyesinde barındırmaktadır (Anonim, British Müzesi 2018).

British Museum'da Osmanlı Dönemi eserlerinin bulunduğu yer Orta Doğu Bölümü olarak isimlendirilmiştir. Orta Doğu Bölümü'nün koleksiyonunda yaklaşık 330.000 nesne yer almaktadır. En önemli parçalar da dahil olmak üzere yaklaşık 4,500 objenin temsili resimleri online olarak sergilenmektedir (Anonim, British Museum, 2018).

Frederick Du Cane Godman (1834-1919) British Museum'daki Klasik Osmanlı seramiklerinin ilk sahibidir. Birçok ülke gezmiş olan Godman bir koleksiyonerdir. Ölümünden sonra koleksiyonu ailesine kalmış ve Horsham Surrey'deki South Lodge'daki evlerinde bir müddet sergilenmiştir. İlk kızı Eya 1965 'te ölmüş ve koleksiyon ikinci kızı Edith'e kalmıştır. Edith Godman bu koleksiyonu ölümünden sonra British Museum'a bırakılmak üzere vasiyet etmiştir. Edith 18 Mayıs 1982 yılında ölmüş, koleksiyon o yılın haziran ayında British Museum'a aktarılmış ve 1983 yılında müze envanterine kaydedilmiştir (Anonim, British Museum, 2018).

Klasik Osmanlı Dönemi Kapalı Formlu Seramikler, Osmanlı Devletinin Klasik olarak adlandırılan döneminde yoğun olarak görülmeye başlamıştır (Henderson, 1989: 64). Kapalı form olarak isimlendirilen bu tip seramiklerin en belirgin tanımlaması ağız veya gövde genişliği kap yüksekliğinden az olan seramik kaplar olarak tanımlanmaktadır (Ökse, 2012: 94). Bu tip kapların ağız açıklıklarının tüm gövdeye oranla dar oluşu ve bu açıklıktan içinin az bir kısmının görülebilmesi gibi nedenlerle üzeri kapalı olmamalarına karşın “kapalı kap” anlamına gelen terimler kullanılmıştır (Karamağralı, 2007: 141). Bu tip kaplar İngilizce kaynaklarda "closed vessels" olarak kullanılmaktadır (Ökse, 2012: 158). Bu türden kapların içerisine maşrapa, bardak, şişe, vazo, sürahi, kandil gibi birçok farklı alanda kullanılan seramik formlar girmektedir.

British Museum'da sergilenen Klasik Osmanlı dönemi kapalı formlu seramikleri altı farklı başıık altında toplanabilen eserlerden oluşmaktadır. Bunlar bardak, ibrik, kandil, kavanoz, maşrapa ve şişe olarak isimlendirilmiştir. Belirlenen başııkların her biri aşağıda ayrı başıklar altında irdelenmiştir.

\section{Bardak:}

Halk arasında genellikle pişmiş toprak, cam, metalden yapılmış testi biçimli su kabına "bardak” denilmektedir. Günümüzde su vb. sıvı maddeleri içmek için kullanılan ve genellikle camdan yapılan kaplara da aynı ad verilmiştir. Arkeolojik yayınlarda kenarı çoğunlukla dışa doğru açılan, ağız veya gövde genişliği kap yüksekliğinden az olan, ağız çapı da genellikle 15 cm'den daha geniş olmayan kaplara "bardak” adı verilmektedir (Ökse, 1999: 57).

Bardak kelimesi, Derleme Sözlüğü’nde “Bardag, Bardak, Bardah” sözcükleri ile ifade edilmiştir. Tarama Sözlüğü’nde ise Bartak, Sagrak, Sugrak kelimeleri eş anlamlı olarak kullanılmıştır. Altın, gümüş gibi değerli metallerle, camın çok yaygın kullanılmadığı 10. yüzyıldan 18. yüzyıla kadar seramik ve sıvı kapları ise Billur, Billur Bardak, Sır Bardak, Billur Kupa gibi isimler almıştır (Şahin, 1999: 76). İngilizce "Tankard Jug” olarak da geçmektedir.

Osmanlı arşivlerinde bu kap tipi için kullanılan terim genellikle “bardak” olarak geçmektedir. Edirne'de 1553'te Mirliva Sinan Bey’e ait malların envanterinde üç kez "bardak” birer kez de "bardağ- İzünik”, “İznik bardağı” ve "bardağ-ı İznik" terimleri geçmektedir (Atasoy, 1989: 25). Yine 1548 tarihli tereke defterlerinde Bölükbaşı Sinan Bin Abdullah isimli kişinin malları arasında çini tas, bardak ve çanak isimlerinin geçtiği görülmektedir (Atasoy, 1989: 27).

Bardaklar, Klasik Osmanlı döneminde içecek koymak için yapılmış en yaygın biçim olmuşlardır (Önder, 2017: 403). Bu tür bardakların 16. yüzyılın başından 17 . yüzyıla değin gövde biçimlerinin ufak değişiklikler geçirdiği görülmektedir. Bununla birlikte boyun uzunluğunun ve oranlarının çeşitli şekillerde yapıldığı örneklerden anlaşılmaktadır (Atasoy, 1989: 45). 


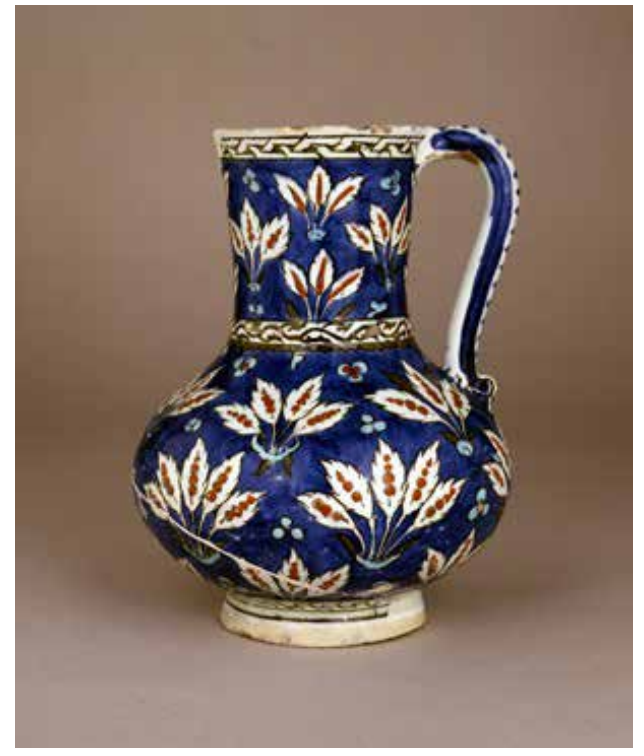

Fotoğraf 1: Bardak, 16.yüzyıl, İznik, British Museum, Londra (Anonim, Bardak, 2013).

Klasik Osmanlı dönemi bardak biçimleri ağız, gövde, taban ve kulp kısımlarından oluşmaktadır. Bu dönemde görülen bardak biçimlerinde en belirgin değişiklik gövde şeklinde meydana gelmiştir. 16. yüzyılın başlarında görülen ilk bardak örnekleri oval bir gövde biçimine sahipken (Fotoğraf 1), 16 yüzyılın ortalarında bu biçim değişerek armudi bir görünüm almıştır (Fotoğraf 2-3).

İlk üretilen oval biçimli bardaklar günümüze çok fazla gelmemiştir. Bu tipte yapılmış bardaklar düz ağızlı, basık oval gövdeli ve tek kulpludur. British Museum'da bu örnekten bir adet bulunmaktadır (Fotoğraf 1 ).
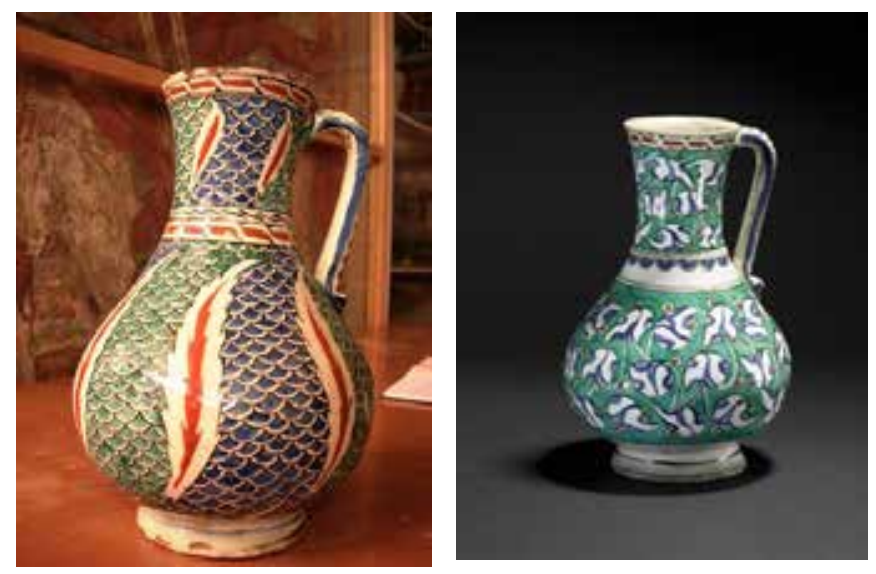

Fotoğraf 2: Bardak, 16.yüzyıl, İznik, British Museum, Londra (Anonim, Bardak, 2013).

Fotoğraf 3: Bardak, 16.yüzyıl, İznik, British Museum, Londra (Anonim, Bardak, 2013).
Armudi gövdeli bardaklar Klasik Osmanlı döneminde en çok üretilmiş örneklerdir. Günümüze sağlam bir şekilde gelmiş olan bu örnekler çeşitli yurt içi ve yurt dışı müzelerinde bulunmaktadır. Geniş düz ağızlı, armudi gövdeli, tek kulplu olarak yapılmış olan bu eserlerden, British Museum'da iki adet örnek bulunmaktadır (Fotoğraf 2-3).

\section{2.İbrik:}

İbrik, günümüzde su koymaya yarayan kulplu emzikli kap olarak tanımlanabilir (Anonim, İbrik, 2018). İbrik kelimesinin kökeninin Arapçadan türediği (Akkoyunlu, 2018: 2) bu kelimenin berk "parlamak" kökünden geldiği bilinmektedir (Bozkurt-Ertuğrul, 1988: 372). Bazı kaynaklarda farsça “abriz" "su döken" kelimesinin Arapçalaşmış şekli olduğu da belirtilmektedir (Subaşı, 2016: 312). Bugün İran'da ve İran etkisinde kalan bazı Orta Asya Türk bölgelerinde ibrik kelimesinin yanı sıra abdestan/abdesdan (ab-dest-dan) tabiri de kullanılmaktadır (Bozkurt-Ertuğrul, 1988: 372).

İbrik su şebekesi olmayan her evde bulunan ve israfı önleyen önemli bir kaptır. İbadete hazırlı safhasında kullanılması bakımından saygınlık kazanmış ve gerek bu özelliği gerekse dengeli, zarif yapısı ile süslemelerde de motif olarak yer almıştır (Bozkurt-Ertuğrul, 1988: 375).

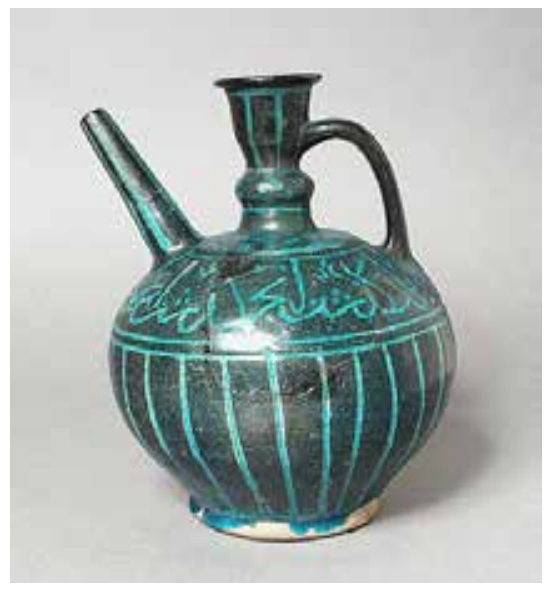

Fotoğraf 4: İbrik, İran, Keşan, 13. yüzyıl, M. Heeramaneck Koleksiyonu, Boy: $21 \mathrm{~cm}$ (Anonim, İbrik, 2015).

Sırlı, sırsız seramik örnekler arasında özellikle 12. yüzyıl sonları ile 13. yüzyıl başlarında Selçuklu sanatında görülen ve çeşitli şehirlerde yapılmış olan ibrikler dikkat çekmektedir. Bu dönemde yapılan modeller oldukça farklıdır. Burada yapılmış olan ibriklerin Osmanlı seramiklerini etkilemiş olduğu günü- 
müze gelen örneklerden anlaşılmaktadır (Fotoğraf 4). Klasik Osmanlı döneminde yapılan ibriklerin bu dönemden etkilenerek yeni modeller ürettikleri söylenebilir.

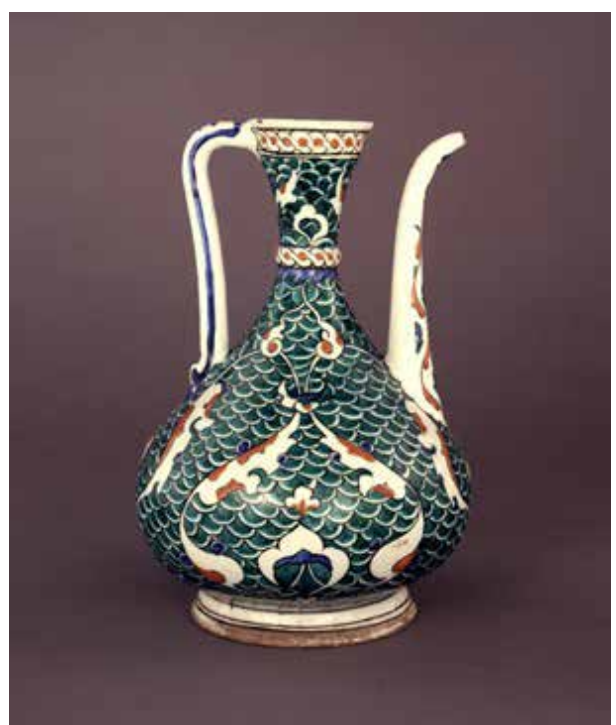

Fotoğraf 5: İbrik, 16.yüzyıl, İznik, British Museum, Londra (Anonim, İbrik, 2013)

British Museum'da sergilenen seramik ibrik örneği, Klasik dönemin sonlarında oldukça fazla karşımıza çıkan ve günümüze kadar da biçimini kaybetmeden gelen formlardandır (Fotoğraf 5). Bu ibrik armudi gövdeli, geniş ağızlı, tek kulplu olarak biçimlendirilmiştir. Boyun, diğer ibrik modellerine göre oldukça dar yapılmıştır. Bu tip ibriklerin, gövdenin en geniş noktasında başlayan emziği ve bunun tam karşısında yer alan kulpu ile bir bütünlük oluşturmaktadır. Emziğin gövde ile birleştiği kısım kalından başlayarak yukarıya doğru daralmaktadır. Emziğin uç kısmı ağız hizasındadır ve dışarı doğru kıvrılmıştır. Taban gövdenin tam ortasındadır.

\section{Kandil:}

Kandil, bir yakıtla fitil içeren ve aydınlatmada kullanılan, toprak, teneke ya da cam kaplara verilen genel bir tanımlamadır. Eski devirlerden beri faydalanılan bir aydınlatma aracıdır. İlk kandillerin muhtemelen dini mekânların içini aydınlatmak, ya da ayinlerde kullanılmak amacıyla işlev görmüş olduğu düşünülmektedir. Kandillerin biçimi ve malzemesi, kullanılma amacı zaman içinde değişmiştir. Seramikten yapılan kandiller insanlar tarafından ucuz olması sebebiyle rağbet gören bir tür olmuştur (Atasoy 1972:1-3). Osmanlı döneminde seramik, tunç, pirinç, cam, gümüş ya da tombaktan (altın yaldızlı ba- kırdan) kandiller yapılmıştır. (Aslanapa 1965; Arseven 1943: 412; Lane 1957; Kolsuk 1976: 73-91; Yetkin 1986). Bu kandiller kısa tabanlı, şişkin gövdeli ve uzun boyunludur (Biçici, 2012: 640).

Latince kökenli olan “Kandil” kelimesi, içine zeytinyağ konularak, bir fitil yardımıyla yakılan aydınlatma aracı anlamını taşımaktadır (Gök, 2004: 34). Kandil mimari eserlerde süs eşyası olmaktan ileri gidememiştir. Fazla aydınlığa müsait olmayışları, çok gölge yapmaları, pahalıya mal oluşlarıyla piyasada hemen hiç revaç görmemişlerdir. Işı̆̆ı daha çok geçiren ve ucuza mal olan cam kandiller çini kandillerin yerini almıştır (Kolsuk, 1976: 73).

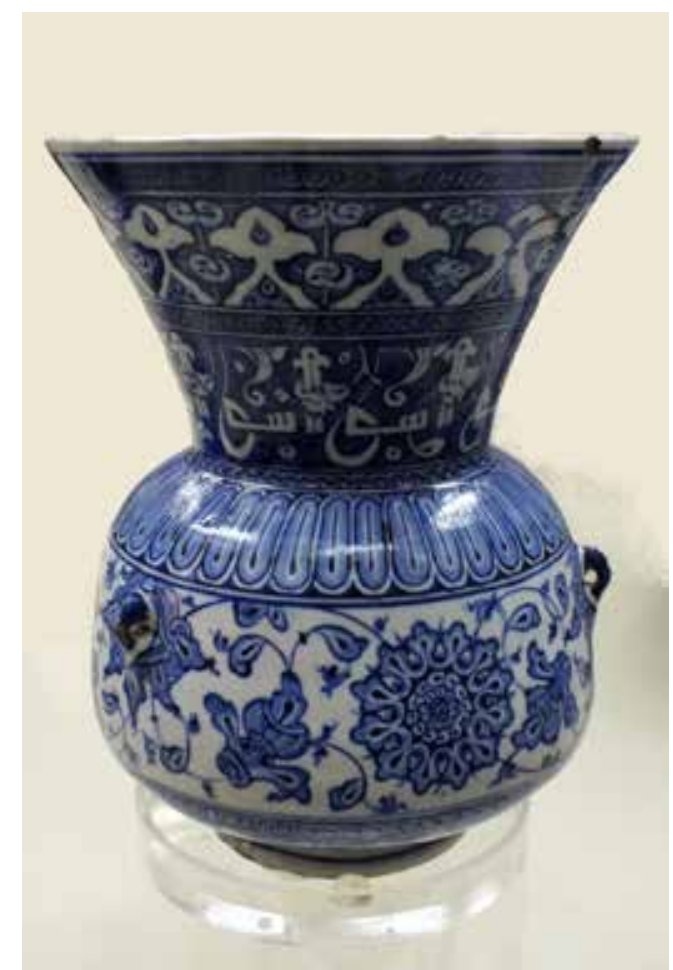

Fotoğraf 6: Kandil, 16.yüzyılın ilk yarısı, İznik, İstanbul Arkeoloji Müzesi (Önder, 2017: 297).

Osmanlı devrinde yapılmış olan seramik cami kandilleri ticari maksat güdülmeden özel sipariş sonucu yapılmış eserlerdir. Türkiye müzelerinde Dünya müzelerinde ve Özel koleksiyonlarda bulunan çini kandillerin miktarı otuzu aşmamaktadır. Bunların en erken tarihli örneği II. Beyazıt türbesinde bulunan 16. yüzyılın başına ait kandildir (Fotoğraf 6), (Önder, 2017: 292).

Klasik Osmanlı Döneminde üretilen kandillerin büyük 
ölçüde günümüze sağlam olarak gelebilmesi ve korunmuş olması, bu örnekleri hangi tiplerde yapıldığını büyük ölçüde göstermektedir. Kandil biçimleri form olarak incelendiğinde boyun, gövde, taban ve kulp kısımlarından oluşmaktadır.
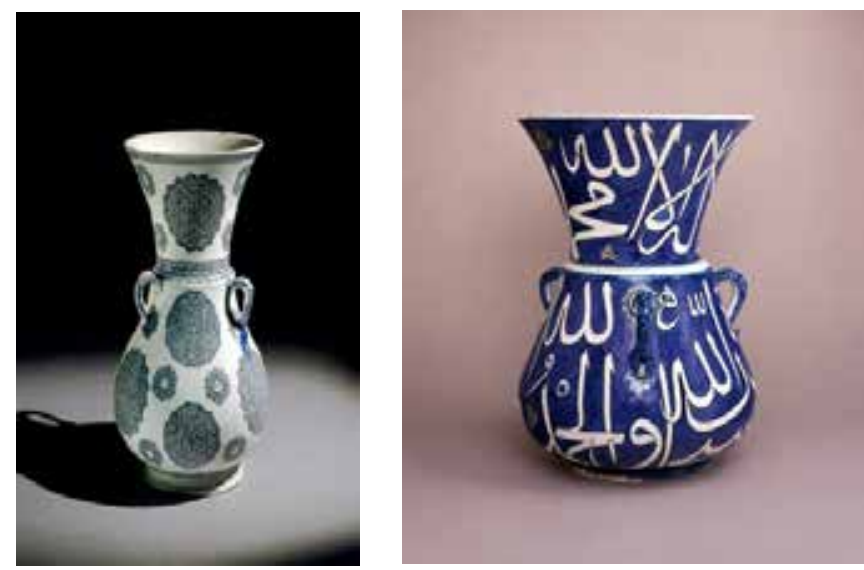

Fotoğraf 7: Kandil, 16.yüzyıl, İznik, British Museum, Londra (Anonim, Kandil, 2013),

Fotoğraf 8: Kandil, 16.yüzyıl, İznik, British Museum, Londra (Anonim, Kandil, 2013)

British Museum'da bulunan kandiller, geniş ağızlı, armudi gövdeli ve üç kulpludur (Fotoğraf 7-8). Kulplar gövdeyi taşıyabilecek biçimde tasarlanmıştır. İki kandilde de kulpların yeri gövde kısmının başladığı noktaya konulmuştur. Bu da kandillerin rahat bir biçimde asılabilmesini sağlamaktadır. Kandillerin ağız kısmı taban kısmına oranlandığında ağız genişliğinin daha fazla olduğu görülmektedir. Bunun sebebi ışığın mekânı daha fazla aydınlatmasının istenmesi olabilir. Bahsedilen kandillerin cidar kalınlıkları 6-7 mm arasında değişmektedir. Kulpların iç kısımlarında cidar kalınlığı bulunmamaktadır. Bu kısımlarda bünye tamamen dolu olarak gövdeye eklenmiştir.

\section{Kavanoz:}

Kavanoz, plastik, cam vb. maddelerden yapılmış ağzı geniş, çeşitli boylarda kap anlamına gelen biçimlerin genel adıdır. Bu tür kapların tarihine bakıldığında eski çağlardan beri süregelen yaygın bir biçim olması bakımından oldukça fazla örneğe sahiptir. Kullanılan bünyenin kalitesi, yapılan kavanozun cidar kalınlığı, boyutları, süslemesi v.b gibi ayrıntılar bunun göstergesidir.

Klasik Osmanlı dönemindeki bazı belgelerde kavanozlar yoğurt kavanozu (kavanos-ı mast) ya da turşu kavanozu (kavanos- ı turşi) olarak işlevlerine göre sınıflandırılmıştır. Bazı narh defterlerinde ise kavanozların boyutlarına göre sınıflandırıldığı bilinmektedir (Atasoy, 1989: 47). Klasik Osmanlı döneminde üretildiği bilinen en eski seramik kavanoz örneği 15. yüzyıla tarihlendirilmektedir ve Atasoy, tarafından Çin porselenlerine benzetilmiştir (Atasoy, 1989: 47).
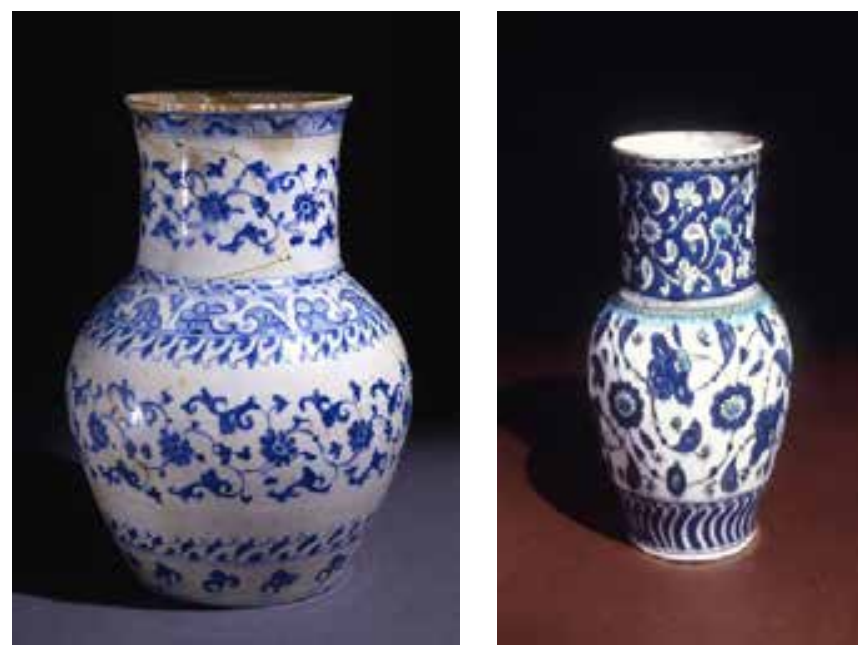

Fotoğraf 9: Kavanoz, 16. yüzyılın başları, British Museum, Londra, Boy: 29,5 cm (Anonim, Kavanoz, 2013).

Fotoğraf 10: Kavanoz, 16. yüzyılın başları, British Museum, Londra, Boy: 29,5 cm (Anonim, Kavanoz, 2013).

British Museum'da bulunan örnekler incelendiğinde üç farklı tipin varlığından söz edilebilir. Bunlardan iki tanesi dışa dönük ağızlı, yukarıya doğru genişleyen şişkin gövdeli kavanozlardır (Fotoğraf 9-10). Omuzdan başlayarak şişkinleşen ve aşağıya doğru inildikçe daralan bir gövde biçimi bu tip kavanozlarda oldukça yaygındır. Bu tip kavanozların ortak özellikleri yaklaşık yirmi santimetreden büyük, geniş ağızı biçimlerdir ve cidar kalınlıkları 5-7 mm civarındadır. Bazı kavanozların tabanları dışarıdan bakıldığında görülebilirken bu formlarda bu durum gözle görülmeyecek biçimde yumuşak geçişli yapılmıştır.

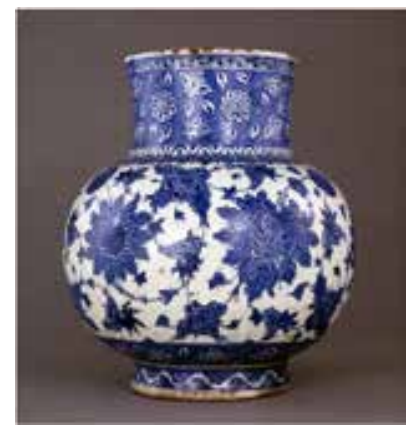

Fotoğraf 11: Kavanoz, Yaklaşık 1510-20, İznik, British Museum, Londra, Boy: 24,5 cm, (Atasoy, 1989: 149). 
British Museum'da bulunan kavanoz örneklerinden bir diğeri, geniş ağızlı, dar boyunlu, gövde kısmının tam orta noktasında genişleyip aşağıya doğru simetrik olarak aynı biçimde daralan yapısıyla farklı bir görünüm sergileyen kavanoz formlarıdır (Fotoğraf 11). Bu tip formların günümüze ulaşan çok fazla örneği bulunmadığı görülmektedir. Kavanozun en-boy oranlarının birbirine neredeyse eşit olması, içerisine konulan her türlü yiyecek ve içeceğin kolay alınmasını sağlayabilir. Bu tip formların ağız açıklıklarının geniş olması içerisine konulan maddelerin kolay tozlanabilmesinin sağladığından bu kapların çok fazla üretilmediği varsayılabilir. Bununla birlikte büyük boyutlu olmaları kolay taşıma olanağını zorlaştırması, çabuk kırılabilmeleri gibi sebeplerden ya çok fazla tercih edilmemişler ya da günümüze sağlam olarak gelememişlerdir. Bu kap biçimlerinin cidar kalınlıkları yaklaşık 5-7 mm arasında değişmektedir.

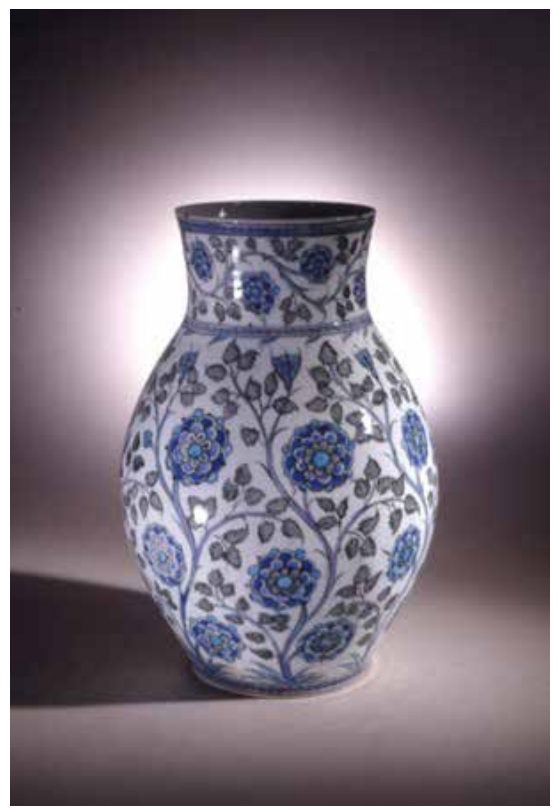

Fotoğraf 12: Kavanoz, 16. yüzyılın başları, British Museum, Londra, Boy: 31,5 cm (Anonim, Kavanoz, 2013).

British Museum'da bulunan kavanozlardan bir başka örnek, geniş düz ağızlı, elips gövdelidir (Fotoğraf 12). Bu kavanozun biçimi boy olarak diğerlerinden daha uzun, en olarak daha ince ve zarif bir görünüme sahiptir. Bu model, diğer kavanoz modellerinde görülen keskin hatların dışında daha yumuşak geçişlerle biçimlendirilmiştir. Bu eser form özellikleri göz önüne alındığında nadir olarak yapılmış olduğu anlaşılmaktadır.

\section{Maşrapa:}

Maşrapa Arapça kökenli bir kelime olup metalden ya da topraktan yapılmış, geniş ağızlı, kulplu, genellikle sıvı madde ya da tahıl aktarma-boşaltma işleminde kullanılan orta boy kaplara verilen isimdir (Ökse, 1999: 57). Günümüzde maşrapa biçimi silindirik gövdeli, tek kulplu olarak yapılmış formlardır. Klasik Osmanlı Dönemi bu tip kapların kimi kaynaklarda "tankart" (Carswell, 2012: 84) olarak geçtiği de görülmektedir. Tankard tipi kaplar düz dipli, yuvarlak kesitli, tek kulplu ya da çift kulplu, düz basit ağız kenarlı ve küresel gövdelidir (Gümüştekin, 2015: 3). Tankart, eski Fransızca'da büyük kulplu içecek kabı anlamına gelen "tanquart"dan türediği bilinmektedir (Ökse, 1999: 58). Tankart kelimesinin genellikle yabancı kaynaklarda geçen bir isim olması ve bu kap biçimleri ile uyuşmaması sebebiyle bu isim kullanılmamış, bunun yerine maşrapa kelimesi daha doğru bir telaffuz olması nedeniyle tercih edilmiştir.

Maşrapa içerisine aldığı sıvı miktarına bağlı olarak çok farklı boyutlarda ve oranlarda yapılmıştır. Atasoy, maşrapa kelimesine 17 . yüzyıla kadar belgelerde rastlanmadığını, terimin daha sonraları kullanılmaya başlandığını belirtmektedir (Atasoy, 1989: 45).

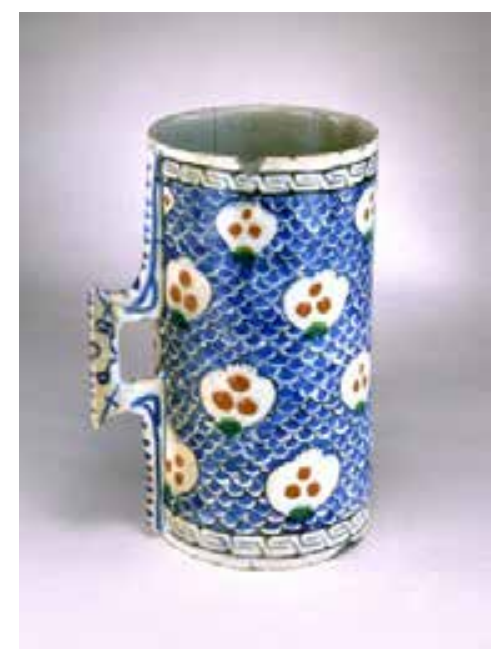

Fotoğraf 13: Maşrapa, 16.yüzyıl, İznik, British Museum, Londra, (env. G 157) (Anonim, Maşrapa, 2013).

British Museum'da bulunan maşrapa örnekleri, genel anlamda gövde, kulp, ağız ve tabandan oluşmaktadır. Kulp gövdeye dik biçimde eklenmiştir. Kulpun tutacak kısmı genellikle gövdenin tam ortasında yer almıştır (Fotoğraf 13-14-15). 
Müzede yer alan maşrapaların cidar kalınlıkları genellikle 5-7 mm civarındadır ve torna yardımı ile biçimlendirildikleri anlaşılmaktadır.
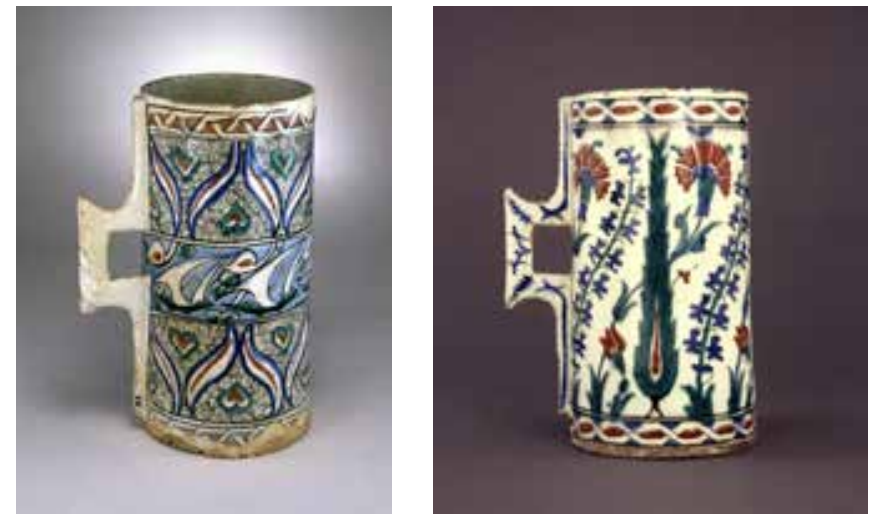

Fotoğraf 14: Maşrapa, 16.yüzyıl, İznik, British Museum, Londra, (env. G 74) (Anonim, Maşrapa, 2013).

Fotoğraf 15: Maşrapa, 16.yüzyıl sonu, İznik, British Museum, Londra, (env. G 59) (Anonim, Maşrapa, 2013).
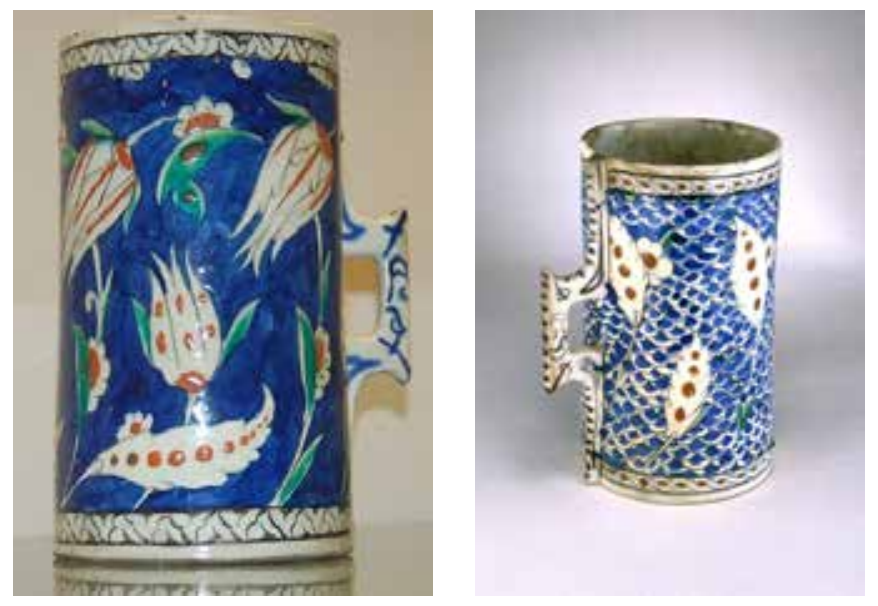

Fotoğraf 16: Maşrapa, 16.yüzyıl sonu, İznik, British Museum, Londra, (env. G 108) (Anonim, Maşrapa, 2013).

Fotoğraf 17: Maşrapa, 16.yüzyıl sonu, İznik, British Museum, Londra, (env. G 156) (Anonim, Maşrapa, 2013).

Maşrapalar içerisine konulan sıvı miktarına bağlı olarak farklı boyutlarda ve oranlarda üretilmiştir. Bu boyut ve oranların bariz farklılıkları maşrapaların alt gruplarının oluşmasını sağlamıştır. British Museum'daki örnekler incelendiğinde üç farklı alt grupta eserlerin olduğu belirlenmiştir. Bunlardan ilk grup 16. yüzyılın ilk yarısında üretilmeye başlanan düz ağızlı, derin, silindirik gövdeli ve tek kulplu olanlardır (Fotoğraf no: 13-14-15-16-17). Gövde, maşrapalarda karakteristik olan silindirik form kullanılarak biçimlendirilmiştir. Kulp gövdeyi tam olarak kaplamaktadır. Kulpların tutacak kısımları kare, dikdörtgen gibi açıklıklar kullanılarak oluşturulmuştur. Kulpun tutacak kısmı gövdeye oranlandığında üçte birine denk gelecek şekilde açıklığı bulunmaktadır.

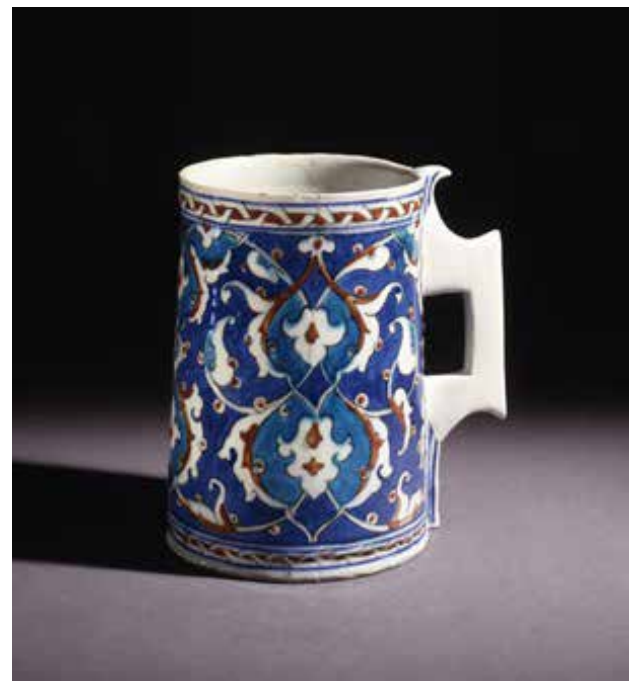

Fotoğraf 18: Maşrapa, 16.yüzyıl, İznik, British Museum, Londra, (env. G 107), (Anonim, Maşrapa, 2013).
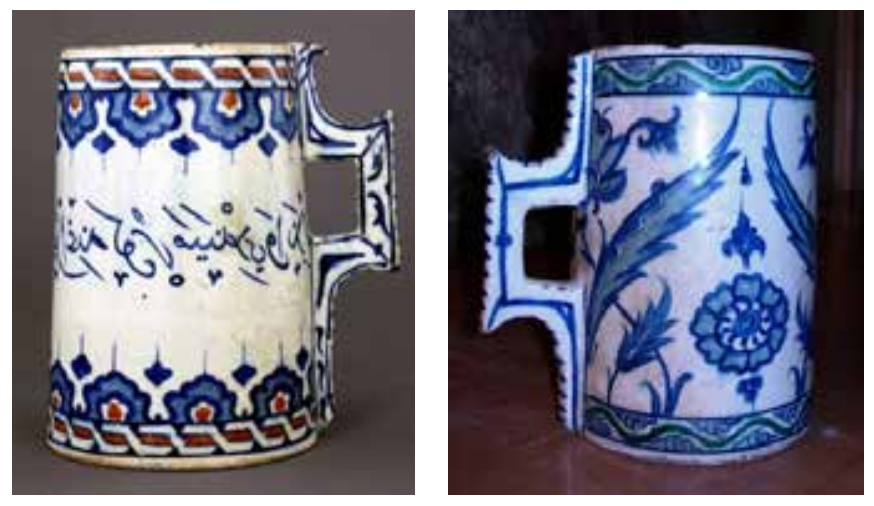

Fotoğraf 19: Maşrapa, 16.yüzyıl, İznik, British Museum, Londra, (env. G 130), (Anonim, Maşrapa, 2013).

Fotoğraf 20: Maşrapa, 16.yüzyıl, İznik, British Museum, Londra, (env. G 154), (Anonim, Maşrapa, 2013).

Maşrapalarda ikinci tip formlar, yaklaşık 16. yüzyılın ikinci yarısında görülmeye başlanan geniş halka tabanlı, basık silindirik gövdeli, düz ağızı ve dikey kulplu olanlardır (Fotoğraf no: 18-19-20). Bu tip biçimlerin bazılarında gövde kısmında aşağıdan yukarıya doğru hafif bir daralma görülebilir (Fotoğraf no: 18-19). Bunun haricinde en büyük değişim kulp kısmında yapılmıştır. Bazı kulplar gövdeyi yukarıdan aşağıya doğru tamamen kaplarken (Fotoğraf no: 20), bazı formların gövdeleri yukarıdan ve aşağıdan belirli mesafeler bırakılarak kulp kısmı oluşturulmuştur (Fotoğraf no: 18-19). Bazı 
maşrapalarda kulpların üst bitim yerlerinde yukarıya doğru bir kıvrım mevcuttur.

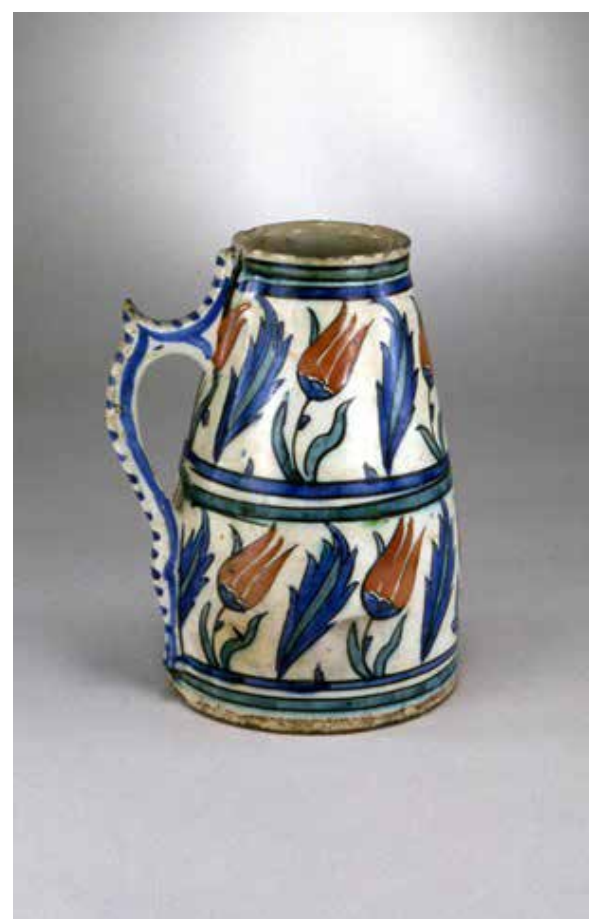

Fotoğraf 21: Maşrapa, 16.yüzyıl, İznik, British Museum, Londra, (env. G 321) (Anonim, Şişe, 2013).

Üçüncü grup olarak belirlenen maşrapa tiplerinde elimizde sadece bir örnek bulunmaktadır (Fotoğraf no: 21). Genel olarak yurt içi ve dışında bulunan müzeler incelendiğinde bu eserin daha geç dönemlerde yaygınlaştı̆ı̆ görülmüştür. Bu türden maşrapalar, aşağıdan yukarıya doğru gözle görünen biçimde daralma görülmektedir. Kulp kısımları diğer maşrapa modellerinde farklıdır. Bunlar biçim açısından metalden yapılmış örneklerine benzetilebilir. Kulp gövdenin tam ortasındadır ve kıvrım biçiminde yapılmıştır. Kulpun gövdeyle birleştiği yerler diğer maşrapa örneklerine göre daha azdır.

\section{6.Şişe:}

Farsça kökenli "şişe" günümüzde sıvı maddelerinin konulduğu dar boyunlu cam kaplara verilen addır. Yüksekliği genişliğinden fazla olan uzunca boyunlu, nadiren boyunsuz, ağız açıklığı kap derinliğinin yarısından dar olan kaplar, aynı adla anılırlar (Ökse, 1999: 62). Şişeler genellikle uzun ince boyunlu olarak tasarlanmıştır. Bunun haricinde kısa, geniş boyunlu olanları da mevcuttur (Atasoy, 1989: 45).

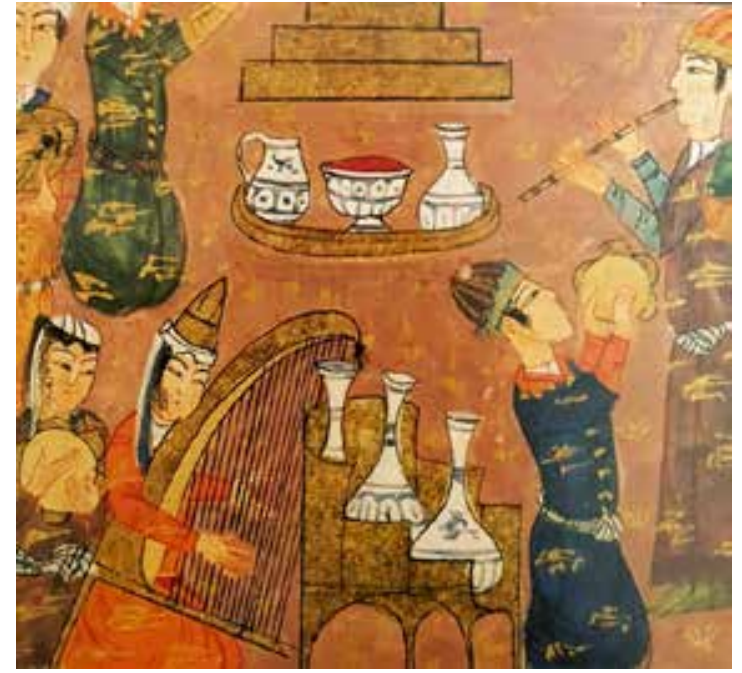

Fotoğraf 22: Eğlence sahnesi, Külliyat- Katibi, Yaklaşık 1460-80, TSMK, İstanbul (ayrıntı), (Atasoy, 1989: 35).

Şişe biçimleri kullanım amaçlarına göre özel olarak tasarlanmışlardır. Kap boyutu, delik çapı, boyun uzunluğu, gövde genişliği gibi forma işlenen özellikler kullanım amacını da belirlemektedir. Şişeler, küçük bir tabandan yukarıya doğru açılan oval gövdeli, dar boğazlı olarak binlerce yıldır popüler ve kullanışlı objeler olmuşlardır (Lane, 1988: 74).

Şişelerin yapılış amaçları araştırıldığında dönemin sünnet düğünleri, yemekleri gibi padişah tarafından verilen önemli davetlerde sofralarda kullanılmış olabileceği, dönemin minyatürlerinden anlaşılmaktadır (Fotoğraf 22). Ayrıca eskiden gelen bir gelenek olan önemli sıvı maddelerin taşımak amacıyla üretildikleri söylenebilir.
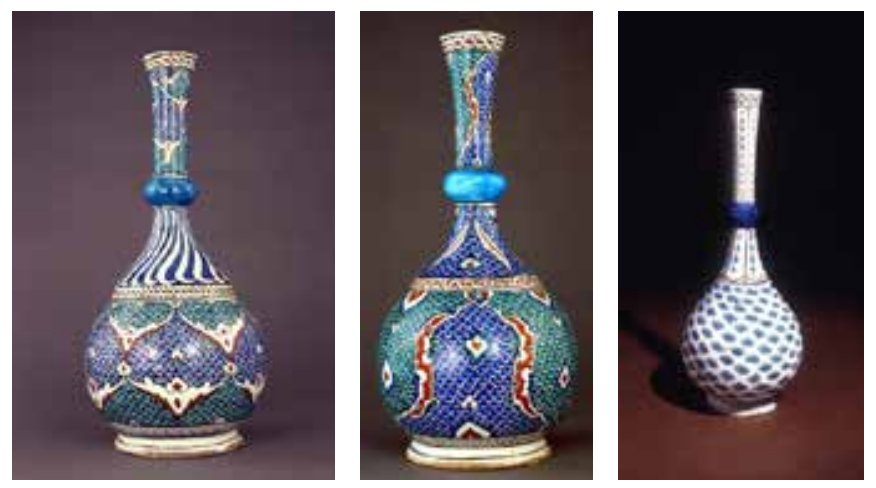

Fotoğraf 23: Şişe, 16.yüzyıl, İznik, British Museum, Londra, (env. G 116) (Anonim, Şişe, 2013).

Fotoğraf 24: Şiş̧e, 16.yüzyıl, İznik, British Museum, Londra, (env. G 83) (Anonim, Şişe, 2013).

Fotoğraf 25: Şişe, 16.yüzyıl, İznik, British Museum, Londra, (env. G 167), (Anonim, Şişe, 2013) 
Klasik Osmanlı dönemi seramik şişe biçimleri gövde, boyun ve taban bölümlerden oluşmaktadır. Şişelerin işlevsel olarak kullanılan bölümü olan gövde en önemli kısmı oluşturmaktadır.
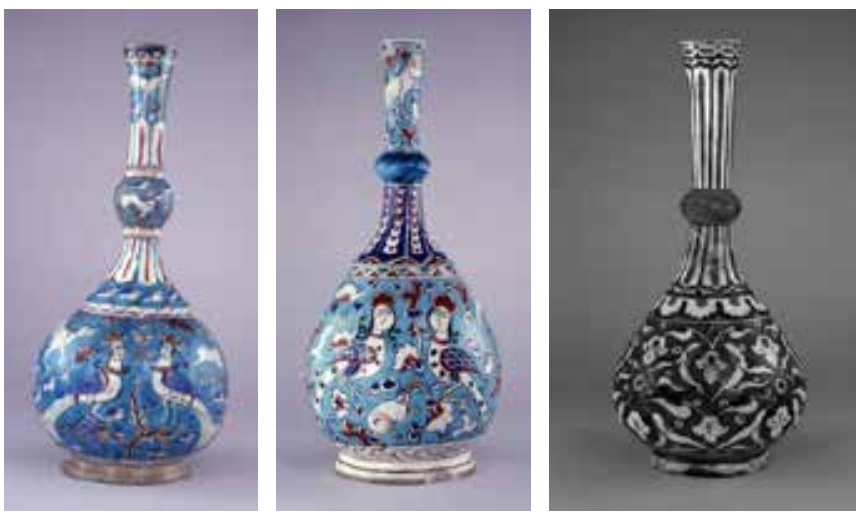

Fotoğraf 26: Şişe, 17.yüzyıl, İznik, British Museum, Londra, (env. G 160), (Anonim, Şişe, 2013).

Fotoğraf 27: Şişe, 17.yüzyıl, İznik, British Museum, Londra, (env. G 161), (Anonim, Sişe, 2013).

Fotoğraf 28: Şişe, 16.yüzyıl, İznik, British Museum, Londra, (env. G 106), (Anonim, Şişe, 2013)

British Museum'da bulunan altı adet eserin hemen hepsi aynı özelliklerde üretilmişs şişelerdir. Bu tip şişelerin genel özellikleri uzun ince boyunlu, armudi gövdeli ve tabanlıdır. Boyun neredeyse gövde yüksekliğinin iki katı kadardır (Fotoğraf 23-24-25-26-27-28). Boynun ortasında küçük, oval bir halka yerleştirilmiştir. Ağız kısmı yukarıya doğru hafifçe açılmıştır. Bu tip şişelerin ağızlarındaki bu açıklık içerisine konan sıvıların kolay bir şekilde akmasına yardımcı olmaktadır.

\section{Sonuç}

Biritish Museum dünyanın sayılı müzelerinden bir tanesi olarak günümüzde hala çok farklı eserleri bir arada barındıran nadir kuruluşlardandır. Bu müzenin içerisinde bulunan Klasik Osmanlı seramiklerinin varlığı, dönemin kap biçimlerini irdeleyebilmek açısından oldukça önemlidir. Müze’de 25 farklı biçim ve tarzda Klasik Osmanlı dönemine ait eser bulunmaktadır. Bunlar alfabetik sıraya göre bardak, ibrik, kandil, kavanoz, maşrapa ve şişe biçimleri olarak belirlenmiştir. Bu biçimlerin her biri gövde yapıları göz önüne alındığında varsa alt gruplar hainde incelenmiştir.

British Museum'daki altı ayrı gruptan en çok eser bulunan grup maşrapa örnekleridir. Bu grup gövde biçimleri dikkate alındığında kendi içerisinde üç alt gruba ayrılmıştır. İlk gruptan beş, ikinci gruptan üç, üçüncü gruptan bir adet eser olmak üzere toplamda dokuz ayrı forma ulaşılmıştır. Müzede yer alan şişeler altı adettir ve tek bir grupta toplanmıştır. Kavanoz üç alt grupta irdelenmiştir. İlk grupta iki adet eser, ikinci grupta bir adet eser, üçüncü grupta bir adet eser olmak üzere toplamda dört esere rastlanmıştır. Bardak iki ayrı alt grupta toplanmıştır. İlk grupta bir, ikinci grupta iki adet eser müzede mevcuttur. Kandil örnekleri tek grup altında toplanmıştır ve iki eser bulunmaktadır. İbrik tek grup altında toplanmıştır ve müzede bir eser yer alır.

Bu eserlerin neredeyse tamamı 16 yüzyıl içerisinde yapılmış olduğu tahmin edilmektedir. Bununla birlikte 17. yüzyılda yapılmış olan iki adet eser bulunmaktadır. 17. yüzyıla tarihlendirilen bu eserler şişe biçimleridir.

British Museum'da bulunan kapalı formlu seramikleri içeren bu çalışma, Klasik Osmanlı eserlerinin form tiplerinin belirlemek ve sınıflandırmak maksadıyla yapılmıştır. Bununla birlikte müzede bulunan Osmanlı dönemi eserlerinin varlığından haberdar olmak ve gelecekte aynı türde bir çalışma yapacak olan araştırmacılara örnek teşkil etmek amaçlanmıştır.

\section{Kaynakça}

Arseven, C. E. (1943). Sanat Ansiklopedisi. İstanbul: Milli Eğitim Basımevi.

Aslanapa, 0. (1965). Anadolu'da Türk Çini ve Keramik Sanatı. İstanbul: Türk Kültürü Araştırma Enstitüsü Yayınları.

Atasoy, N.-J.Raby, (1989). İznik Seramikleri, İstanbul: TEB Yayınları.

Akkoyunlu, Z. (2018-03-09). “Divanu Lugati't-Türk'te Evirik (İbrik)".http://www.turkbilig.com/pdf/200917-85.pdf adresinden alınmıştır.

Biçici, H. K. (2012). “İznik Müzesindeki Kandil ve Şamdan Motifli Mezar Taşları”, Turkish Studies-International Periodical For The Languages, Literature and History of Turkish or Turkic Volume 7/3, Summer, s. 637-661, Ankara.

Bozkurt, N.-Ertuğrul, S. (1988). “İbrik” TDV İslam Ansiklopedisi, cilt: 21, s.372-376. http://www.tdvislamansiklopedisi.org/ dia/pdf/c21/c210289.pdf Erişim tarihi:13.07.2015.

Carswell, J. (2012). Iznik Pottery, London, The British Museum Press.

Gök, S. (2004). “2000 Yılı Beçin Kazısı’nda Bulunan Cam Kandil Hakkında” Sanat Tarihi Dergisi, Sayı: XIII/I, Nisan, s.33-41.

Gümüştekin, M. N. (2015). “Orta Anadolu'da Depas ve Tankard Tipi Kaplar"https://www.academia.edu/13288623/0rta Anadoluda_Depas_ve_Tankard_Tipi_Kaplar 
Henderson, J. (1989). “Teknik Açıdan İznik Seramikleri”, İznik Seramikleri, TEB yayınları, İstanbul, s.64-68.

Karamağralı, N. (2007). “Ahlat Sırlı Seramikleri”, Anadolu'da Türk Devri Çini ve Seramikleri, İstanbul, Kültür ve Turizm Bakanlığı Yayınları.

Kolsuk, A. (1976). “Osmanlı Devri Çini Kandilleri”, Türk Etnografya Dergisi, Ankara, S.XV, s.73-91.

Lane, A. (1957). Later Islamic Pottery, Persia, Syria, Egypt, Turkey, London: Faber\&Faber.

Lane, P. (1988). Ceramic Form, London: Colins Sons \& Co.

Ökse, A. T. (1999). Ön Asya Arkeolojisi Seramik Terimleri, İstanbul: Arkeoloji ve Sanat Yayınları.

Önder, A.M. (2017).” Türkiye Müzelerindeki Klasik Osmanlı Dönemi Kapalı Formlu Seramikler" (Yayınlanmamış Doktora Tezi), Konya: Selçuk Üniversitesi Sosyal Bilimler Enstitüsü, Sanat Tarihi Anabilim Dalı.

Şahin, F. K. (1999).“Kulplu İznik Çini Bardaklarr”, Antik Dekor, Sayı: 55, İstanbul, Kasım-Aralı, s.76-84. http://www. antikalar.com/kulplu-iznik-cini-bardaklar/ erişim tarihi: 12.10.2015.

Subaşı, E. (2016). “Sivas Maden Sanatına Ait Örneklerden Bir Grup İbrik” Yüzüncü Yıl Üniversitesi Sosyal Bilimler Enstitüsü Dergisi, Van, sayı: 30, s.307-323.

Yetkin, Ş. (1986). Anadolu'da Türk Çini Sanatının Gelişmesi, İstanbul: İstanbul Üniversitesi, Edebiyat Fakültesi.

\section{Görsel Kaynakça}

Anonim. (2013, 05 28). Bardak. British Museum: http://www. britishmuseum.org/research/collection_online/collection_ object_details.aspx?objectId=236538\&partId=1\&searchTe $\mathrm{xt}=$ ottoman+ceramic\&page $=2$ adresinden alınmıştır

Anonim. (2013, 05 28). Bardak. British Museum: http://www. britishmuseum.org/research/collection_online/collection_ object_details.aspx?objectId $=215438$ \&partId $=1$ \&searchTe $\mathrm{xt}=$ ottoman+ceramic\&page $=2$ adresinden alınmıştır

Anonim. (2013, 05 28). Bardak. British Museum: http://www. britishmuseum.org/research/collection_online/collection_ object_details.aspx?objectId=236545\&partId=1\&searchTe $\mathrm{xt}=$ ottoman+ceramic\&page $=2$ adresinden alınmıştır

Anonim. (2013, 05 28). İbrik. British Museum: http://www. britishmuseum.org/research/collection_online/collection_ object_details.aspx?objectId=236558\&partId=1\&searchTe $\mathrm{xt}=$ ottoman+ceramic\&page $=2$ adresinden alınmıştır

Anonim. (2018, 03 09). İbrik. Türk Dil Kurumu: http://www.tdk.gov. $\mathrm{t} r / \mathrm{i} n \mathrm{~d}$ e $\mathrm{x}$. p h p ? o p t i o $\mathrm{n}=\mathrm{com}$. gts\&kelime $=\% C 4 \% B 0 B R \% C 4 \% B 0 K$ adresinden alınmıştır

Anonim. (2013, 05 28). Kandil. British Museum: http://www. britishmuseum.org/research/collection_online/collection_ object_details.aspx?objectId=236534\&partId=1\&searchTe $\mathrm{xt}=$ ottoman+ceramic\&page $=3$ adresinden alınmıştır
Anonim. (2013, 05 28). Kandil. British Museum: http://www. britishmuseum.org/research/collection_online/collection_ object_details.aspx?objectId=236551\&partId=1\&searchTe $\mathrm{xt}=$ ottoman+ceramic\&page=3 adresinden alınmıştır

Anonim. (2013, 05 28). Kavanoz. British Museum: http://www. britishmuseum.org/research/collection_online/collection. object_details.aspx?objectId=236583\&partId=1\&searchTe $\mathrm{xt}=$ ottoman+ceramic\&page $=2$ adresinden alınmıştır

Anonim. (2013, 05 28). Kavanoz. British Museum: http://www. britishmuseum.org/research/collection_online/collection. object_details.aspx?objectId=215476\&partId=1\&searchTe $\mathrm{xt}=$ ottoman+ceramic\&page $=2$ adresinden alınmıştır

Anonim. (2013, 05 28). Maşrapa. British Museum: http://www. britishmuseum.org/research/collection_online/collection_ object_details.aspx?objectId=215454\&partId=1\&searchTe $\mathrm{xt}=$ ottoman+ceramic\&page $=2$ adresinden alınmıştır

Anonim. (2013, 05 28). Maşrapa. British Museum: :(http://www. britishmuseum.org/research/collection_online/collection. object_details.aspx?objectId=215465\&partId=1\&searchTe $\mathrm{xt}=$ ottoman+ceramic\&page $=2$ adresinden alınmıştır

Anonim. (2013, 05 28). Maşrapa. British Museum: http://www. britishmuseum.org/research/collection_online/collection. object_details.aspx?objectId=215432\&partId=1\&searchTe $\mathrm{xt}=$ ottoman+ceramic\&page $=2$ adresinden alınmıştır

Anonim. (2013, 05 28). Maşrapa. British Museum: http://www. britishmuseum.org/research/collection_online/collection_ object_details.aspx?objectId=215433\&partId=1\&searchTe $\mathrm{xt}=$ ottoman+ceramic\&page $=2$ adresinden alınmıştır

Anonim. (2013, 05 28). Maşrapa. British Museum: http://www. britishmuseum.org/research/collection_online/collection_ object_details.aspx?objectId=215453\&partId=1\&searchTe $\mathrm{xt}=$ ottoman+ceramic\&page $=2$ adresinden alınmıştır

Anonim. (2013, 05 28). Maşrapa. British Museum: http://www. britishmuseum.org/research/collection_online/collection object_details.aspx?objectId=215435\&partId=1\&searchTe $\mathrm{xt}=$ ottoman+ceramic\&page $=3$ adresinden alınmıştır

Anonim. (2013, 05 28). Şişe. British Museum: http://www. britishmuseum.org/research/collection_online/collection. object_details.aspx?objectId=215425\&partId=1\&searchTe $\mathrm{xt}=$ ottoman+ceramic\&page $=2$ adresinden alınmıştır

Anonim. (2013, 05 28). Şişe. British Museum: http://www. britishmuseum.org/research/collection_online/collection_ object_details.aspx?objectId=215428\&partId=1\&searchTe $\mathrm{xt}=$ ottoman+ceramic\&page $=2$ adresinden alınmıştır

Anonim. (2013, 05 28). Şişe. British Museum: http://www. britishmuseum.org/research/collection_online/collection object_details.aspx?objectId=215429\&partId=1\&searchTe $\mathrm{xt}=$ ottoman+ceramic\&page $=2$ adresinden alınmıştır

Anonim. (2013, 05 28). Şişe. British Museum: http://www. britishmuseum.org/research/collection_online/collection. object_details.aspx?objectId=236556\&partId=1\&searchTe $\mathrm{xt}=$ ottoman+ceramic\&page $=2$ adresinden alınmıştır 
Anonim. (2013, 05 28). Şişe. British Museum: http://www. britishmuseum.org/research/collection_online/collection_ object_details.aspx?objectId=236554\&partId=1\&searchTe $\mathrm{xt}=0$ ttoman+ceramic\&page $=2$ adresinden alınmıştır

Anonim. (2013, 05 28). Şişe. British Museum: http://www. britishmuseum.org/research/collection_online/collection_ object_details.aspx?objectId=236573\&partId=1\&searchTe $\mathrm{xt}=0$ ttoman+ceramic\&page $=2$ adresinden alınmıştır

Anonim. (2013, 05 28). Şişe. British Museum: http://www. britishmuseum.org/research/collection_online/collection_ object_details.aspx?objectId=215389\&partId=1\&searchTe $\mathrm{xt}=$ ottoman+ceramic\&page $=2$ adresinden alınmıştır 